Bull. Chem. Soc. Ethiop. 2021, 35(2), 399-412.

(c) 2021 Chemical Society of Ethiopia and The Authors

ISSN 1011-3924

DOI: https://dx.doi.org/10.4314/bcse.v35i2.13

Printed in Ethiopia

Online ISSN 1726-801X

\title{
PREPARATION, SPECTROSCOPIC, THERMAL AND MOLECULAR DOCKING STUDIES OF COVID-19 PROTEASE ON THE MANGANESE(II), IRON(III), CHROMIUM(III) AND COBALT(II) CREATININE COMPLEXES
}

\author{
Mohamed Y. El-Sayed ${ }^{1 *}$, Moamen S. Refat ${ }^{2}$, T. Altalhi ${ }^{2}$, Hala H. Eldaroti ${ }^{3}$ and Kehkashan \\ Alam $^{4}$ \\ ${ }^{1}$ Chemistry Department, College of Science, Jouf University, P.O. Box 2014, Sakaka, Saudi \\ Arabia \\ ${ }^{2}$ Department of Chemistry, College of Science, Taif University, P.O. Box 11099, Taif 21944, \\ Saudi Arabia \\ ${ }^{3}$ Department of Chemistry, Faculty of Education, Alzaeim Alazhari University, Khartoum, \\ Sudan \\ ${ }^{4}$ Department of Chemistry, Faculty of Science, Aligarh Muslim University, Aligarh, 202002, \\ India
}

(Received March 2, 2021; Revised September 9, 2021; Accepted September 9, 2021)

\begin{abstract}
Creatinine biomolecule has three different coordination modes through the (exocyclic $\mathrm{O}(5)$ and ring $\mathrm{N}(1)$ ), (imine $\mathrm{N}(2)$ and ring $\mathrm{N}(1)$ ) or as monodentate ligand via exocyclic $\mathrm{O}(1)$ ). The FTIR and electronic spectra of the synthesized manganese(II), iron(III), chromium(III), and cobalt(II) complexes consistent with the coordinated behavioral derived from the structural analyses. Thermogravimetric data agree with the stoichiometry and proposed formulas $\left[\mathrm{Mn}\left(\mathrm{C}_{4} \mathrm{H}_{7} \mathrm{~N}_{3} \mathrm{O}\right)_{2}(\mathrm{Cl})_{2}\right] 4 \mathrm{H}_{2} \mathrm{O},\left[\mathrm{Fe}\left(\mathrm{C}_{4} \mathrm{H}_{7} \mathrm{~N}_{3} \mathrm{O}\right)_{2}(\mathrm{Cl})_{2}\right] \mathrm{Cl}_{6} 6 \mathrm{H}_{2} \mathrm{O},\left[\mathrm{Cr}\left(\mathrm{C}_{4} \mathrm{H}_{7} \mathrm{~N}_{3} \mathrm{O}\right)_{2}(\mathrm{Cl})_{2}\right] \mathrm{Cl}_{2} 6 \mathrm{H}_{2} \mathrm{O}$, and $\left[\mathrm{Co}\left(\mathrm{C}_{4} \mathrm{H}_{7} \mathrm{~N}_{3} \mathrm{O}\right)_{2}(\mathrm{Cl})_{2}\right] 6 \mathrm{H}_{2} \mathrm{O}$. Four new transition metal complexes derived from the reaction of creatinine chelate and metal salt $\left(\mathrm{MnCl}_{2} \cdot 4 \mathrm{H}_{2} \mathrm{O}, \mathrm{FeCl}_{3} \cdot 6 \mathrm{H}_{2} \mathrm{O}, \mathrm{CrCl}_{3} \cdot 6 \mathrm{H}_{2} \mathrm{O}\right.$, and $\mathrm{CoCl}_{2} \cdot 6 \mathrm{H}_{2} \mathrm{O}$ ), were prepared with 1:2 (metal: ligand) stoichiometry, isolated and well characterized by a different spectral and analytical techniques including FTIR, UV/Vis, magnetic susceptibility, molar conductance, elemental analysis, and TGA/DrTGA/DTA. The solid complexes were formed with the binding of the creatinine ligand through exocyclic $O(5)$ and ring $N(1)$ and presented as an octahedral geometry. In addition molecular docking calculations have been performed between complexes of manganese(II), iron(III), chromium(III) and cobalt(II) with creatinine biomolecule ligand with the Covid-19 protease (6LU7) to determine the best binding site and its inhibitory effect.
\end{abstract}

KEY WORDS: Creatinine, Coordination, Transition metals, TGA/DTA, Octahedral geometry

\section{INTRODUCTION}

Creatinine is a physiological component of blood, brain, and muscles and an important bioligand, which is the last product of the nitrogen metabolism in the vertebrates. Creatinine (2amino-1,5 dihydro-1-methyl-4-H-imidazol-4-one; molecular formula, $\mathrm{C}_{4} \mathrm{H}_{7} \mathrm{~N}_{3} \mathrm{O}$ ), being a natural metabolite of creatin, is a very important bioligand [1-3]. The presence of several donor groups in its main tautomeric form determines its strong coordination capacity. The importance of creatinine in clinical chemistry is well recognized; its level in serum and urine is indicative of the renal function. The latter participates in energy flow in muscle tissues and is present in blood, muscles, and the brain $[1,2]$. The complexation ability of creatinine is well recognized and studies on the metal ion interactions with creatinine may be helpful in deciphering creatinine metabolic pathways [4-7]. The study of binary and ternary complexes of this ligand should be of interest since creatinine metabolism might be connected with its complexation to different metal ions [8]. Five co-ordination modes have been established by X-ray crystallography: bidentate bridging through $\mathrm{N}(\mathrm{l})$ (ring) and deprotonated exocyclic NH site [9], bidentate binding via $\mathrm{N}(1)$ (ring) and the exocyclic $\mathrm{O}(\mathrm{C}=\mathrm{O})[10]$; monodentate binding through

*Corresponding author. E-mail: iyosri@yahoo.com

This work is licensed under the Creative Commons Attribution 4.0 International License 
the $\mathrm{N}(\mathrm{l})$ (ring)site [11]; monodentate binding through the exocyclic $\mathrm{O}(\mathrm{C}=\mathrm{O})$ [12]; and monodentate fashion through the deprotonated exocyclic NH group [10]. Creatinine is soluble in water and in aqueous solution it shows acidic properties $\left(\mathrm{pK}_{\mathrm{a}}=4.89\right)$ [13]. The interaction of $\mathrm{Pt}(\mathrm{II})$ with creatinine is studied in different reaction conditions. At L:M ratio from 4 to 10 several new complexes of Pt(II) are obtained, studied by spectroscopic methods and X-ray diffraction. In these monomeric species the ligand is coordinated only through the endogenic nitrogen [13]. Additionally, the tautomeric equilibrium of creatinine in aqueous solutions was studied and two tautomers (Figure 1) are found to coexist by comparing its experimental and calculated Raman spectra. A water dimer being used to solvate creatinine would make the thermodynamic energy favourable to convert from the imino tautomer to the amino tautomer $[12,13]$.

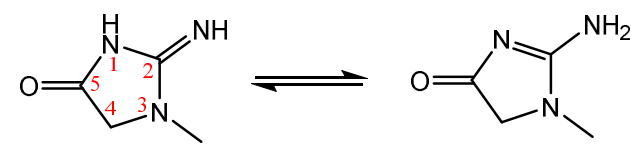

Figure 1. Tautomeric form of creatinine molecule.

In this article, the $\mathrm{Mn}(\mathrm{II}), \mathrm{Fe}(\mathrm{III}), \mathrm{Cr}(\mathrm{III})$, and $\mathrm{Co}(\mathrm{II})$ creatinine complexes were isolated in solid state and their tentative structures were assigned on the basis of their elemental analyses, molar conductance, magnetic susceptibility measurements, thermal and spectral data. Another goal of this paper is to investigate the interaction of COVID-19 proteases with the Mn(II), $\mathrm{Fe}(\mathrm{III}), \mathrm{Cr}(\mathrm{III})$, and $\mathrm{Co}(\mathrm{II})$ creatinine complexes using a technique known as molecular docking that gives free energy to the binding sites, the bond surfaces hydrogen bonds represent H-bonds.

\section{EXPERIMENTAL}

\section{Chemicals and instruments}

All the chemicals and the solvents were purchased from Sigma-Aldrich Chemical Company and used without further purification. The FT-IR spectra were recorded in the range $4000-400 \mathrm{~cm}^{-1}$ on Bruker FTIR Spectrophotometer. The electronic spectra of the synthesized creatinine complexes were recorded in the range $200-800 \mathrm{~nm}$ at room temperature in the solid state using a UV2 Unicam UV/Vis Spectrophotometer. Microanalyses (C, H and N) of the complexes were recorded on a Perkin Elmer $2400 \mathrm{CHN}$ analyzer. Melting points of the compounds were determined in open capillaries in an electrical MPS10-120 melting point apparatus. The magnetic moments of the complexes were determined on a Guoybalance, and the diamagnetic corrections of the complexes were calculated using Pascal's constants. Molar conductivities of the complexes were measured in DMSO solution at $10^{-3} \mathrm{M}$ concentration using a Jenway 4010 conductivity meter. The metal contents were estimated with a gravimetrically method. Thermogravimetric analysis of the complexes was performed from room temperature to $800{ }^{\circ} \mathrm{C}$ using a TGA/DTA-50H Shimadzu thermal analyzer.

\section{Synthesis of creatinine complexes}

All the complexes were synthesized by the same methodology, briefly a methanolic solution of the freshly prepared creatinine ligand was added in portions to the corresponding metal salt $\left(\mathrm{MnCl}_{2} \cdot 4 \mathrm{H}_{2} \mathrm{O}, \mathrm{FeCl}_{3} \cdot 6 \mathrm{H}_{2} \mathrm{O}, \mathrm{CrCl}_{3} \cdot 6 \mathrm{H}_{2} \mathrm{O}\right.$, and $\left.\mathrm{CoCl}_{2} \cdot 6 \mathrm{H}_{2} \mathrm{O}\right)$ solution in the same solvent in $2: 1$ molar ratio. Instantly, precipitation occurred; colors of the precipitates depended upon the metals. The precipitate was filtered and washed with excess of distilled water, then methanol 
and in the end with diethyl ether to remove unreacted ligand and impurities, then the complexes stored under vacuum over anhydrous $\mathrm{CaCl}_{2}$.

\section{Computational and molecular docking details}

AutoDock 4.2 was utilized to perform the docking calculations on COVID-19 protease (6LU7) obtained from the online protein data bank (http://www.rcsb.org) [14]. Avogadro v.1.2. used to optimize the geometries of all the of all four metal complex structures. With the support of AutoDock tools, rotatable bonds and roots of ligand were identified. Also, polar hydrogen atoms and gasteiger charge into the COVID-19 protease were added and $\mathrm{H}_{2} \mathrm{O}$ molecules were removed from the 6LU7. Further, Lamarkian Genetic Alogrithm was applied for docking simulations. The conformations obtained was analyzed and visualized through discovery studio program [15] with the lowest binding energy.

\section{RESULTS AND DISCUSSION}

\section{Elemental and conductance data}

In our study, the manganese(II), iron(III), chromium(III), and cobalt(II) creatinine complexes were synthesized by the reaction of creatinine ligand with four transition metal chloride $\left(\mathrm{MnCl}_{2} \cdot 4 \mathrm{H}_{2} \mathrm{O}, \mathrm{FeCl}_{3} \cdot 6 \mathrm{H}_{2} \mathrm{O}, \mathrm{CrCl}_{3} \cdot 6 \mathrm{H}_{2} \mathrm{O}\right.$, and $\left.\mathrm{CoCl}_{2} \cdot 6 \mathrm{H}_{2} \mathrm{O}\right)$ in $1: 2$ ratio (metal : ligand) in methanol with a yield of $70-77 \%$. The synthesized complexes were found to be stable at room temperature and soluble in DMSO and DMF. Molar conductance data of the metal complexes were measured in DMSO at $10^{-3} \mathrm{M}$ and the $\left[\mathrm{Mn}\left(\mathrm{C}_{4} \mathrm{H}_{7} \mathrm{~N}_{3} \mathrm{O}\right)_{2}(\mathrm{Cl})_{2}\right] 4 \mathrm{H}_{2} \mathrm{O}$ and $\left[\mathrm{Co}\left(\mathrm{C}_{4} \mathrm{H}_{7} \mathrm{~N}_{3} \mathrm{O}\right)_{2}(\mathrm{Cl})_{2}\right] 6 \mathrm{H}_{2} \mathrm{O}$ complexes showed conductance in the range of $22-29 \mathrm{ohm}^{-1} \mathrm{~cm}^{2} \mathrm{~mol}^{-1}$ at ambient temperature indicating non-electrolytic in nature [8], while the $\left[\mathrm{Fe}\left(\mathrm{C}_{4} \mathrm{H}_{7} \mathrm{~N}_{3} \mathrm{O}\right)_{2}(\mathrm{Cl})_{2}\right] \mathrm{Cl} .6 \mathrm{H}_{2} \mathrm{O}$ and $\left[\mathrm{Cr}_{2}\left(\mathrm{C}_{4} \mathrm{H}_{7} \mathrm{~N}_{3} \mathrm{O}\right)_{2}(\mathrm{Cl})_{2}\right] \mathrm{Cl}_{6} 6 \mathrm{H}_{2} \mathrm{O}$ complexes showed conductance in the range of $55-62 \mathrm{ohm}^{-1} \mathrm{~cm}^{2} \mathrm{~mol}^{-1}$ at ambient temperature indicating electrolytic in nature [13] and outside their coordination sphere there is one chloride counter ion present. The thermal nature of the complexes has been obtained by TGA, DrTGA/DTA analysis. The analytical and physical data of creatinine metal complexes are presented in Table 1 . The formation of creatinine complexes frameworks and bidentate $\mathrm{ON}$ donor nature of the creatinine with metal ions for the formation of complexes were obtained from characteristic band positions in FTIR, electronic spectra, magnetic properties, thermal and elemental analysis. These data of the metal complexes suggest that metal to ligand ratio of the metal complexes 1:2 stoichiometry of the types $\left[\mathrm{Mn}\left(\mathrm{C}_{4} \mathrm{H}_{7} \mathrm{~N}_{3} \mathrm{O}\right)_{2}(\mathrm{Cl})_{2}\right] 4 \mathrm{H}_{2} \mathrm{O}$ and $\left[\mathrm{Co}\left(\mathrm{C}_{4} \mathrm{H}_{7} \mathrm{~N}_{3} \mathrm{O}\right)_{2}(\mathrm{Cl})_{2}\right] 6 \mathrm{H}_{2} \mathrm{O}$, $\left[\mathrm{Fe}\left(\mathrm{C}_{4} \mathrm{H}_{7} \mathrm{~N}_{3} \mathrm{O}\right)_{2}(\mathrm{Cl})_{2}\right] \mathrm{Cl} .6 \mathrm{H}_{2} \mathrm{O}$ and $\left[\mathrm{Cr}\left(\mathrm{C}_{4} \mathrm{H}_{7} \mathrm{~N}_{3} \mathrm{O}\right)_{2}(\mathrm{Cl})_{2}\right] \mathrm{Cl}_{6} 6 \mathrm{H}_{2} \mathrm{O}$ where $\mathrm{C}_{4} \mathrm{H}_{7} \mathrm{~N}_{3} \mathrm{O}$ is creatinine ligand as shown in Figure 2.

Table 1. Microanalytical and physical analysis results for creatinine complexes.

\begin{tabular}{|c|c|c|c|c|c|c|}
\hline \multirow[t]{2}{*}{ Compounds } & \multirow[t]{2}{*}{ Color } & \multirow{2}{*}{$\begin{array}{l}\text { Yield } \\
(\%)\end{array}$} & \multirow{2}{*}{$\begin{array}{c}\text { Conductance } \\
\left(\mathrm{ohm}^{-1} \mathrm{~cm}^{2} \mathrm{~mol}^{-1}\right)\end{array}$} & \multicolumn{3}{|c|}{$\begin{array}{c}\text { Analysis } \\
\text { Found } /(\text { calcd }) \% \\
\end{array}$} \\
\hline & & & & $\mathrm{C}$ & $\mathrm{H}$ & $\mathrm{N}$ \\
\hline $\mathrm{C}_{4} \mathrm{H}_{7} \mathrm{~N}_{3} \mathrm{O}$ & White & - & 11 & 42.43 & 6.19 & 37.13 \\
\hline $\begin{array}{l}{\left[\mathrm{Mn}\left(\mathrm{C}_{4} \mathrm{H}_{7} \mathrm{~N}_{3} \mathrm{O}\right)_{2}(\mathrm{Cl})_{2}\right] 4 \mathrm{H}_{2} \mathrm{O}} \\
\mathrm{Mwt}=424.14 \mathrm{~g} / \mathrm{mol}\end{array}$ & $\begin{array}{l}\text { Light } \\
\text { brown }\end{array}$ & 77 & 22 & $\begin{array}{c}22.33 \\
(22.65) \\
\end{array}$ & $\begin{array}{c}5.21 \\
(5.23) \\
\end{array}$ & $\begin{array}{r}19.75 \\
(19.81) \\
\end{array}$ \\
\hline $\begin{array}{l}{\left[\mathrm{Fe}\left(\mathrm{C}_{4} \mathrm{H}_{7} \mathrm{~N}_{3} \mathrm{O}\right)_{2}(\mathrm{Cl})_{2}\right] \mathrm{Cl}_{6} 6 \mathrm{H}_{2} \mathrm{O}} \\
\mathrm{Mwt}=496.53 \mathrm{~g} / \mathrm{mol}\end{array}$ & Brown & 70 & 55 & $\begin{array}{c}19.29 \\
(19.35)\end{array}$ & $\begin{array}{c}5.26 \\
(5.28) \\
\end{array}$ & $\begin{array}{c}19.87 \\
(16.93) \\
\end{array}$ \\
\hline $\begin{array}{l}{\left[\mathrm{Cr}\left(\mathrm{C}_{4} \mathrm{H}_{7} \mathrm{~N}_{3} \mathrm{O}\right)_{2}(\mathrm{Cl})_{2}\right] \mathrm{Cl}_{2} 6 \mathrm{H}_{2} \mathrm{O}} \\
\mathrm{Mwt}=492.68 \mathrm{~g} / \mathrm{mol}\end{array}$ & $\begin{array}{l}\text { Dark } \\
\text { green }\end{array}$ & 74 & 62 & $\begin{array}{c}19.41 \\
(19.50) \\
\end{array}$ & $\begin{array}{c}5.29 \\
(5.32) \\
\end{array}$ & $\begin{array}{c}17.03 \\
(17.06) \\
\end{array}$ \\
\hline $\begin{array}{l}{\left[\mathrm{Co}\left(\mathrm{C}_{4} \mathrm{H}_{7} \mathrm{~N}_{3} \mathrm{O}\right)_{2}(\mathrm{Cl})_{2}\right] 6 \mathrm{H}_{2} \mathrm{O}} \\
\mathrm{Mwt}=464.16 \mathrm{~g} / \mathrm{mol}\end{array}$ & Violet & 73 & 29 & $\begin{array}{c}20.57 \\
(20.70) \\
\end{array}$ & $\begin{array}{c}5.43 \\
(5.65) \\
\end{array}$ & $\begin{array}{r}18.05 \\
(18.11) \\
\end{array}$ \\
\hline
\end{tabular}

Bull. Chem. Soc. Ethiop. 2021, 35(2) 


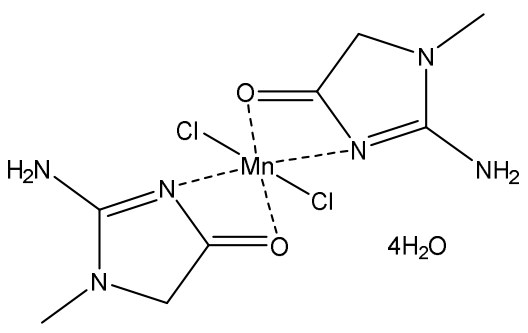

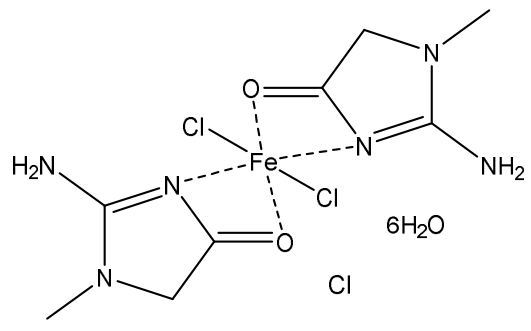<smiles></smiles>

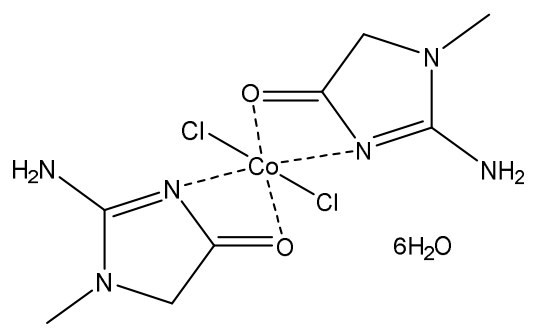

Figure 2. Suggested structures of creatinine complexes.

The synthesized complexes have high melting points $\left(>250{ }^{\circ} \mathrm{C}\right)$. The experimental data obtained from elemental analysis and analytical data are in good agreement to support 1:2 metal to ligand stoichiometry. The coordinated chloride ions analysis of the complexes indicated two chlorine atoms per molecule.

\section{Infrared spectra}

Creatinine ligand can coordinate through the ring nitrogen, the $\mathrm{C}=\mathrm{O}$ and/or $-\mathrm{NH}_{2}$ groups. In metal complexes, creatinine usually coordinates to the metal via the ring nitrogen [3-10]. The infrared frequencies of the free creatinine ligand and the solid synthesized complexes of $\mathrm{Mn}$ (II), $\mathrm{Fe}(\mathrm{III}), \mathrm{Cr}(\mathrm{III})$, and $\mathrm{Co}(\mathrm{II})$ metal ions were scanned within the FTIR region of $4000-400 \mathrm{~cm}^{-1}$ (Figure $3 \mathrm{a}-\mathrm{e}$ ) and compared with that of the free ligand. The assignments of characteristic bands $\left(\mathrm{cm}^{-1}\right)$ for creatinine, according to the data mentioned in the literature [4-10] are: $v\left(\mathrm{NH}_{\text {cyclic }}\right) / v_{\text {as }} \mathrm{NH}=3264 \mathrm{~cm}^{-1} ; v\left(\mathrm{NH}_{\text {imino }}\right) / v_{\mathrm{s}} \mathrm{NH}_{2}=3021 \mathrm{~cm}^{-1} ; v(\mathrm{C}(5)=\mathrm{O})+v(\mathrm{C}=\mathrm{N})=1799$ and $1696 \mathrm{~cm}^{-1} ; \mathrm{v}(\mathrm{C}=\mathrm{N})=1628 \mathrm{~cm}^{-1}$. The infrared spectra of the creatinine complexes are shown in Figure 3 as representative illustration. In case of the spectra of the four creatinine complexes, changes in frequency and intensity are detected on the bands corresponding to stretching vibrations $v(\mathrm{NH})$. A few bands are exhibit at region $3368-3139 \mathrm{~cm}^{-1}$ which suggest the presence of the creatinine ligand in its amino tautomer form (Figure 1) [4-7]. The strong band at 1799 $\mathrm{cm}^{-1}$ assigned to $v(\mathrm{C}(5)=\mathrm{O})$ in the free creatinine ligand spectrum shifts to lower frequencies at about $1716-1690 \mathrm{~cm}^{-1}$ region upon complexation $\left(109-83 \mathrm{~cm}^{-1}\right)$. The stretching frequency bands with $v(\mathrm{C}=\mathrm{N})$ contribution at 1696 and $1628 \mathrm{~cm}^{-1}$ are shifted to $1669-1642 \mathrm{~cm}^{-1}$ and $1598-1589 \mathrm{~cm}^{-1}$ regions because of the new charge distribution in the configuration of the ring system. The shifts to lower wavenumbers of the $v(\mathrm{C}=\mathrm{O})$ in the complexes can be attributed to 
the effect of coordination through the oxygen atom of the exocyclic $\mathrm{O}(\mathrm{C}=\mathrm{O})$ group to the metal [8]. To determine the coordination site of creatinine complexes, the wave numbers of creatinine in complexes are compared with those of free creatinine. Some selected fundamental modes of complexes are reported in Table 2. It was observed few bands corresponding to stretching vibrations $v\left(\mathrm{NH}_{2}\right)$ and their wavenumbers are found to be higher in value than those of free creatinine. A shifted to higher wavenumber is usually regarded as signifying that the ligand is not $\mathrm{NH}_{2}$ bonded. These results suggested that the $\mathrm{NH}_{2}$ group of creatinine does not involved in the coordination with the metal ions and are in good agreement with those reported in the literature [8]. The bands at $1500-1498 \mathrm{~cm}^{-1}, 1428-1404 \mathrm{~cm}^{-1}$, and $1339-1333 \mathrm{~cm}^{-1}$, and $687-$ $670 \mathrm{~cm}^{-1}$ with ring contribution exhibit intensity changes and shift to higher wavenumbers $\left(27-10 \mathrm{~cm}^{-1}\right)$ in complexes. All these data suggest binding between the metal (II/III) ions towards the exocyclic $\mathrm{O}(\mathrm{C}=\mathrm{O})$ group and ring $\mathrm{N}$ atom of the creatinine. In the $600-400 \mathrm{~cm}^{-1}$ area of the spectra is resolved two weak bands at $585-577 \mathrm{~cm}^{-1}$ and $420-407 \mathrm{~cm}^{-1}$ which are assigned to $v(\mathrm{M}-\mathrm{O})$ and $v(\mathrm{M}-\mathrm{N})$, respectively [16].

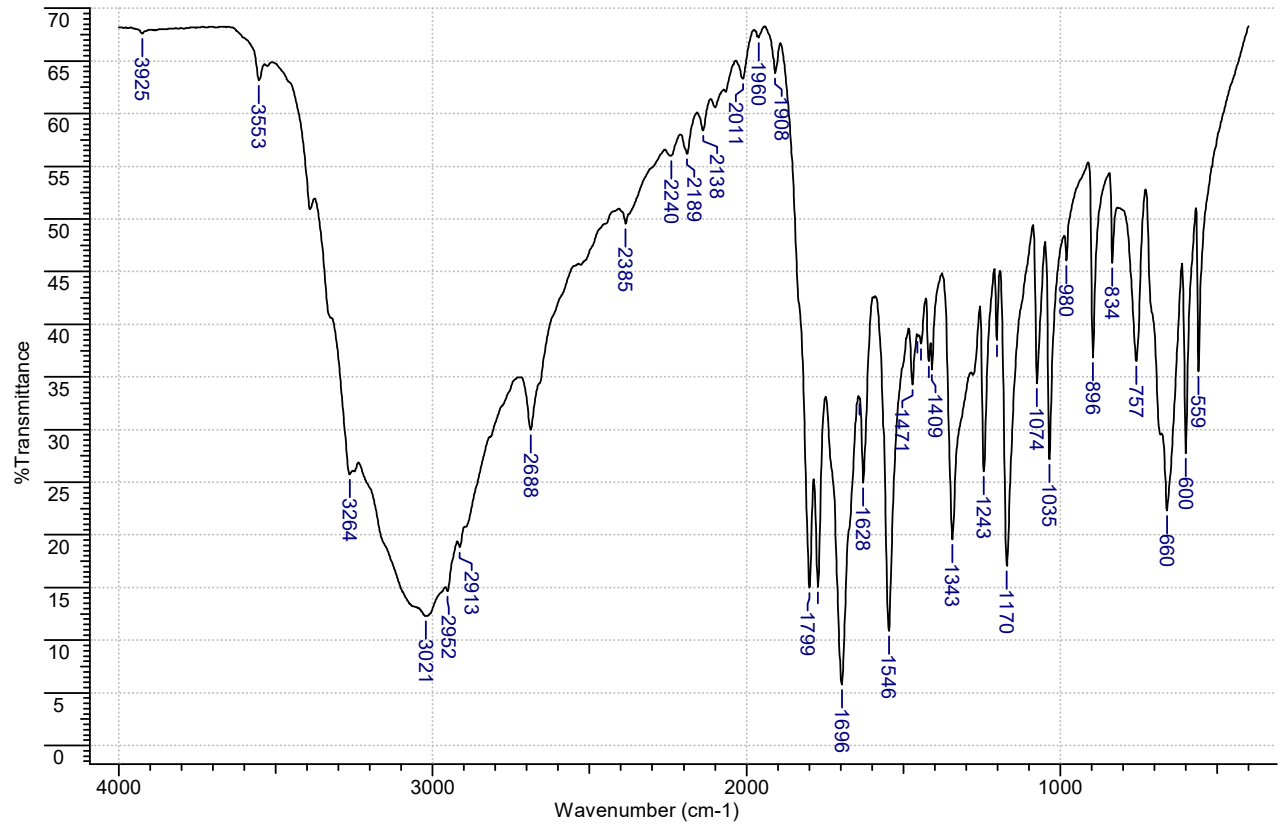

Figure 3a. FTIR spectrum of creatinine ligand. 


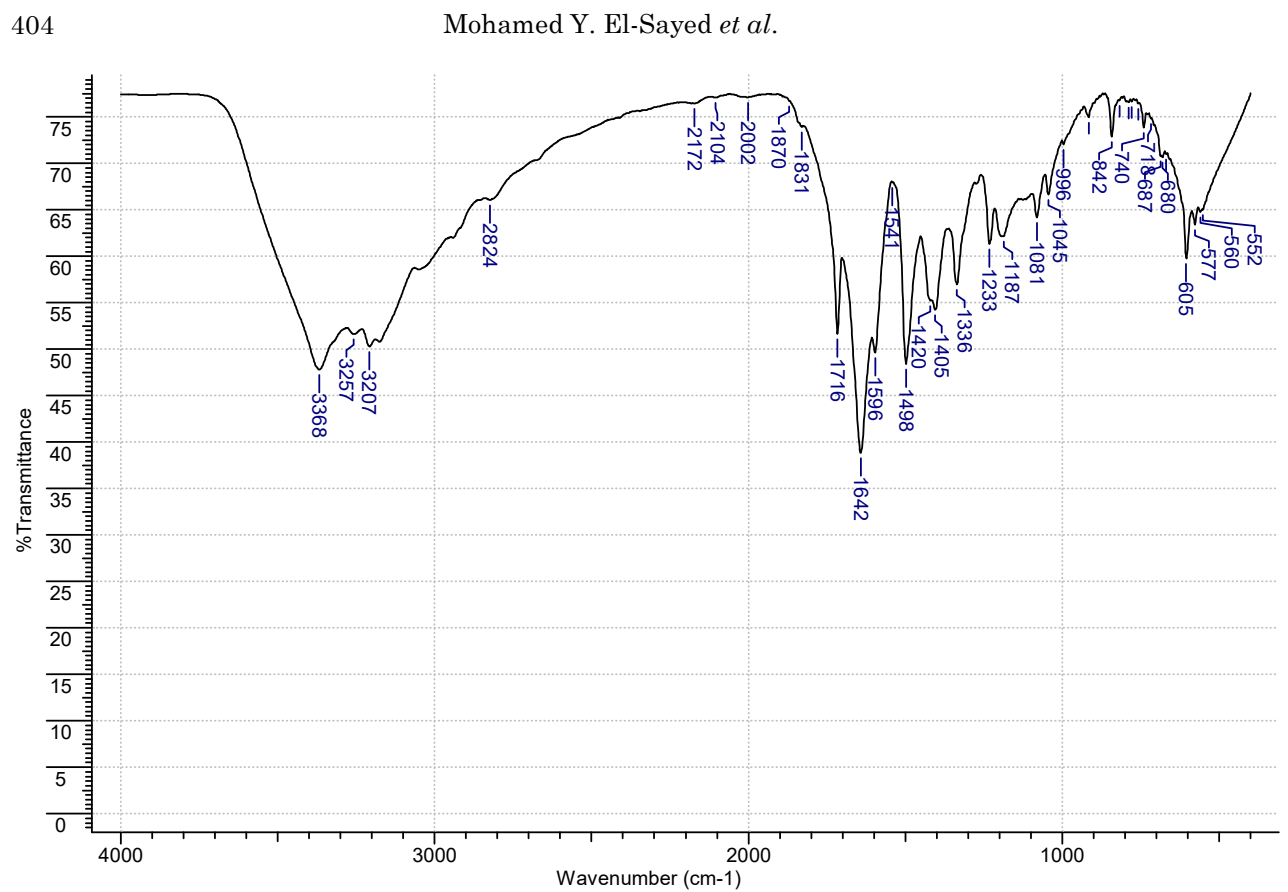

Figure 3b. FTIR spectrum of manganese(II) complex.

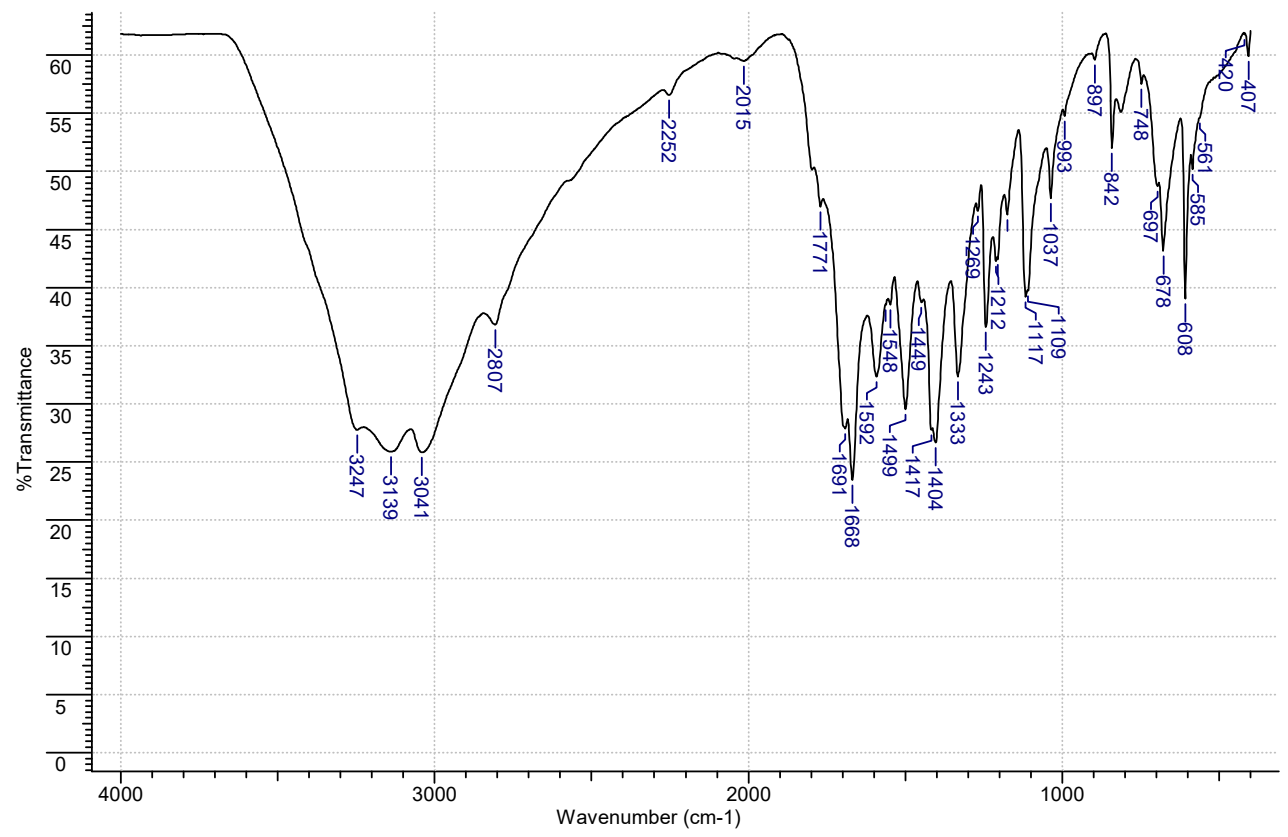

Figure 3c. FTIR spectrum of iron(III) complex.

Bull. Chem. Soc. Ethiop. 2021, 35(2) 
Preparation, of manganese(II), iron(III), chromium(III) and cobalt(II) creatinine complexes

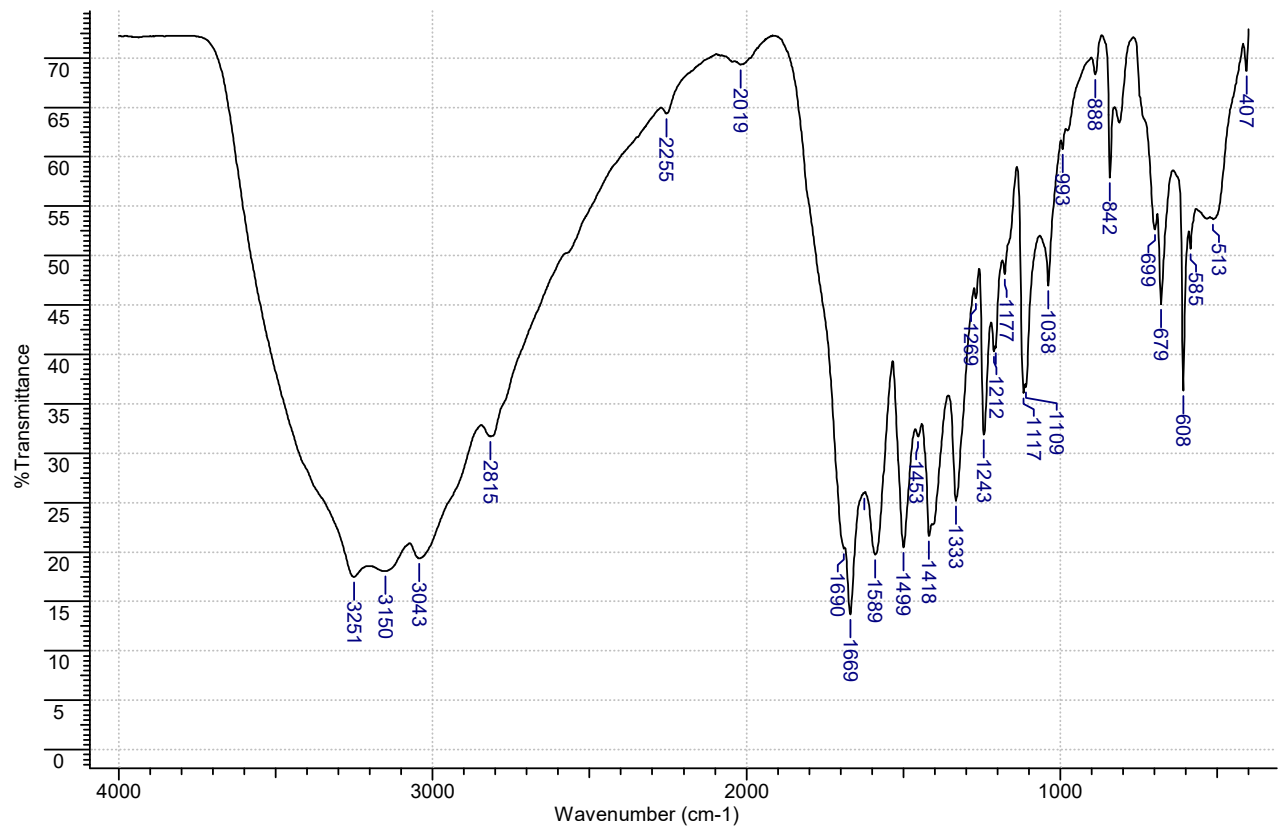

Figure 3d. FTIR spectrum of chromium(III) complex.

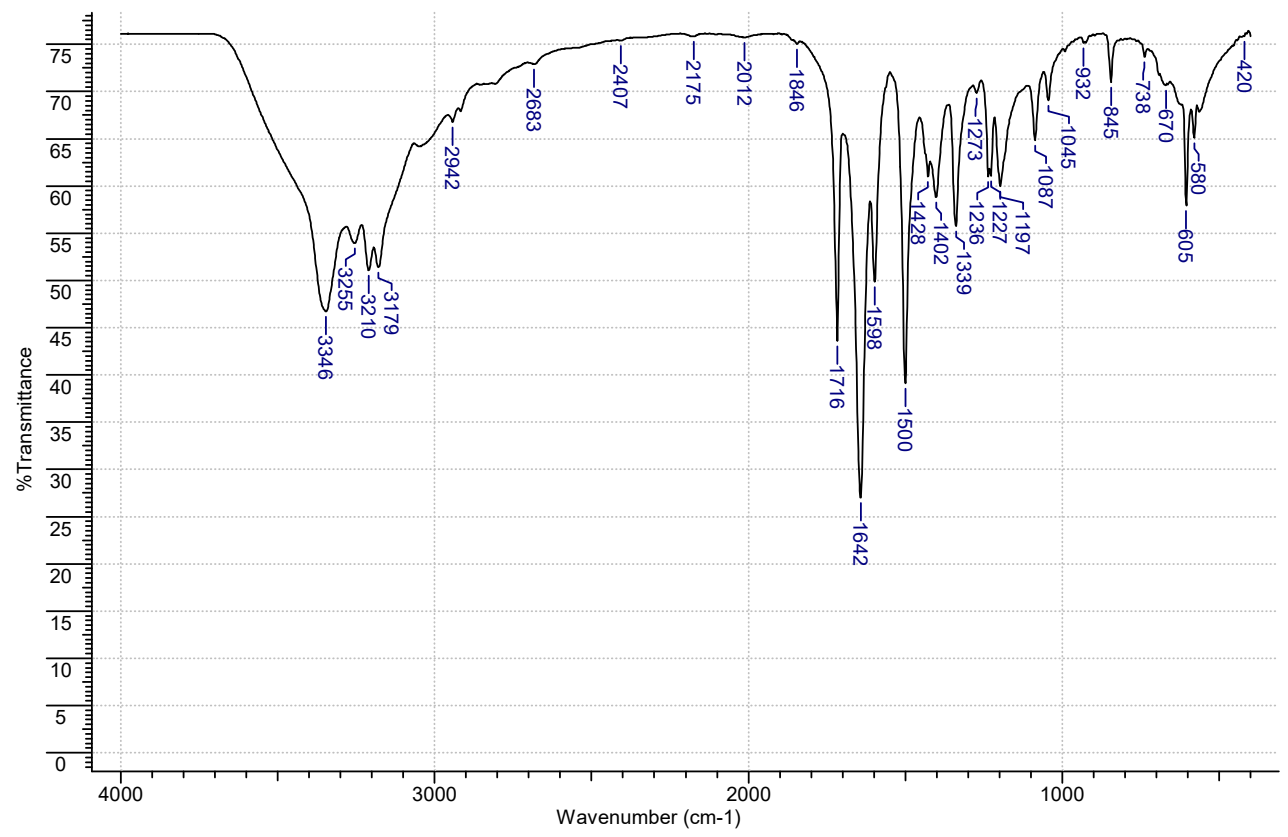

Figure 3e. FTIR spectrum of cobalt(II) complex.

Bull. Chem. Soc. Ethiop. 2021, 35(2) 
Table 2. Infrared spectral assignments of the creatinine and its complexes.

\begin{tabular}{|l|l|l|l|l|l|}
\hline Creatinine & $\mathrm{Mn}(\mathrm{II})$ & $\mathrm{Fe}(\mathrm{III})$ & $\mathrm{Cr}(\mathrm{III})$ & $\mathrm{Co}(\mathrm{II})$ & Assignments \\
\hline 3264 & $\begin{array}{l}3368,3257 \\
3207\end{array}$ & 3247,3139 & 3251,3150 & $\begin{array}{l}3346,3255 \\
3210,3179\end{array}$ & $v(\mathrm{~N}(1)-\mathrm{H})+v_{\mathrm{as}}\left(\mathrm{NH}_{2}\right)$ \\
\hline 3021 & 3034 & 3041 & 3043 & 3035 & $v(\mathrm{NH})_{\text {imino }}+v_{\mathrm{s}}\left(\mathrm{NH}_{2}\right)$ \\
\hline 1799 & 1716 & 1691 & 1690 & 1716 & $v(\mathrm{C}(5)=\mathrm{O})$ \\
\hline 1696,1628 & 1642,1596 & 1668,1592 & 1669,1589 & 1642,1598 & $v(\mathrm{C}=\mathrm{N})$ \\
\hline- & 577,552 & 585 & 585,513 & 580 & $v(\mathrm{M}-\mathrm{O})$ \\
\hline- & 410 & 407 & 407 & 420 & $v(\mathrm{M}-\mathrm{N})$ \\
\hline
\end{tabular}

\section{UV-Vis spectra and magnetic susceptibility}

The $\pi-\pi^{*}$ transition band at $235 \mathrm{~nm}$ for the creatinine free ligand increases its relative intensity appearing at 242-255 $\mathrm{nm}$ in the spectra of the manganese(II), iron(III), chromium(III), and cobalt(II) complexes in DMSO solvent. The electronic absorption spectrum of manganese(II) complex contains three bands at 675,411 and $383 \mathrm{~nm}$ assignable to the transitions ${ }^{6} \mathrm{~A}_{1 \mathrm{~g}} \rightarrow{ }^{4} \mathrm{~T}_{1 \mathrm{~g}}$, ${ }^{6} \mathrm{~A}_{1 \mathrm{~g}} \rightarrow{ }^{4} \mathrm{~T}_{2 \mathrm{~g}}$ and charge transfer, respectively. Magnetic moment value 5.90 BM matches with standard value (5.92 BM) corresponds octahedral geometry for $\mathrm{Mn}(\mathrm{II})$ complex [17]. The electronic absorption spectra of iron(III) complex show three strong bands at 765, 534 and 315 $\mathrm{nm}$ which may be assigned to the transitions ${ }^{6} \mathrm{~A}_{1 \mathrm{~g}} \rightarrow{ }^{4} \mathrm{~T}_{1 \mathrm{~g}}(4 \mathrm{D}),{ }^{6} \mathrm{~A}_{1 \mathrm{~g}} \rightarrow{ }^{4} \mathrm{~T}_{1 \mathrm{~g}}$ and charge transfer respectively. Electronic transitions together with magnetic moment value 5.80 BM indicates high spin octahedral geometry for iron(III) complex [17]. In the chromium(III) complex two transitions bands are observed, they are ${ }^{4} \mathrm{~A}_{2 \mathrm{~g}} \rightarrow{ }^{4} \mathrm{~T}_{2 \mathrm{~g}}\left(v_{1}\right)$, and ${ }^{4} \mathrm{~A}_{2 \mathrm{~g}} \rightarrow{ }^{4} \mathrm{~T}_{1 \mathrm{~g}}\left(v_{2}\right)$, the third transition ${ }^{4} \mathrm{~A}_{2 \mathrm{~g}}(\mathrm{~F}) \rightarrow{ }^{4} \mathrm{~T}_{1 \mathrm{~g}}(\mathrm{P})$ which could not be identified, it lies in the ligand field. The corresponding energy levels for the transitions are 566 and $379 \mathrm{~nm}$, respectively. The spectral transitions suggest that the geometry of the complex is octahedral around the central $\mathrm{Cr}^{3+}$ ion [17] which is also supported by its magnetic susceptibility value (3.74 BM). The cobalt(II) complex show three bands at 820,450 and $353 \mathrm{~nm}$ which may be attributed to the transitions ${ }^{4} \mathrm{~T}_{1 \mathrm{~g}} \rightarrow{ }^{4} \mathrm{~T}_{2 \mathrm{~g}}(\mathrm{~F}),{ }^{4} \mathrm{~T}_{1 \mathrm{~g}} \rightarrow{ }^{4} \mathrm{~A}_{2 \mathrm{~g}}(\mathrm{~F})$ and charge transfer respectively. Electronic transitions along with magnetic moment value 4.49 B.M. suggest high spin octahedral geometry for Co(II) complex [17]. The octahedral geometry is further supported by ratio $v 2 / v 1=1.822$ which is close to the value expected for octahedral geometry.

\section{Thermal analysis}

TGA study was carried out between $30-1000{ }^{\circ} \mathrm{C}$; thermograms (Figure $4 \mathrm{a}-\mathrm{d}$ ) showed gradual weight loss, indicating decomposition by fragmentation with increase in temperature. For all synthesized creatinine complexes, following steps were observed (i) small weight loss in the range of $30-150{ }^{\circ} \mathrm{C}$ assignable to the loss of uncoordinated water molecules, (ii) maximum weight loss in the range of $150-300{ }^{\circ} \mathrm{C}$ which is attributable to the loss of coordinated chloride ions and one of creatinine molecule, and (iii) gradual weight loss in the range of $300-1000{ }^{\circ} \mathrm{C}$ that can be assigned to complete decomposition of ligand moiety around the metal ion respectively and finally the complex is converted into its metal oxide. Thermograms of synthesized creatinine complexes are plotted in Figure $4 \mathrm{a}-\mathrm{d}$; showing approximately $78-88 \%$ weight loss up to $1000^{\circ} \mathrm{C}$ which is according to the above-mentioned three steps.

In the TG curve of $\mathrm{Mn}$ (II) complex, the first step of decomposition from $30{ }^{\circ} \mathrm{C}$ to $150{ }^{\circ} \mathrm{C}$, with a mass loss $8.76 \%$ (calcd. $8.49 \%$ ), an endothermic peak $\Delta \mathrm{T}_{\max }=142{ }^{\circ} \mathrm{C}$ in DTA may be attributed to the removal of two molecules of non-coordinated water molecules. The second decomposition step from $150{ }^{\circ} \mathrm{C}$ to $350{ }^{\circ} \mathrm{C}$ with mass loss $39.97 \%$ (calcd. $39.50 \%$ ), an exothermic peak $\Delta \mathrm{T}_{\max }=310{ }^{\circ} \mathrm{C}$ attributed to the removal of two molecules of non-coordinated water, chlorine gas, and part of the first creatinine molecules. The third step starts from $350{ }^{\circ} \mathrm{C}$ 
to $1000{ }^{\circ} \mathrm{C}$ with mass loss $36.57 \%$ (calcd. $36.40 \%$ ) an exothermic peak is observed at $\Delta \mathrm{T}_{\max }=$ $608{ }^{\circ} \mathrm{C}$ in DTA corresponds to decomposition of coordinated part of creatinine ligand. The mass of the final residue corresponds to stable $\mathrm{MnO}, 15.72 \%$ (calcd. $16.72 \%$ ).

The thermal profile of $\mathrm{Fe}(\mathrm{III})$ complex shows mass loss $27.56 \%$ (calcd. $28.90 \%$ ) in the range $30-250{ }^{\circ} \mathrm{C}$ and an endothermic peak in this region $\Delta \mathrm{T}_{\max }=242{ }^{\circ} \mathrm{C}$ indicates loss of six uncoordinated water molecules and one chlorine atom. The anhydrous complex second decomposition from $250{ }^{\circ} \mathrm{C}$ to $400{ }^{\circ} \mathrm{C}$ with mass $24.66 \%$ (calcd. $24.20 \%$ ) loss and an endothermic $\Delta \mathrm{T}_{\max }=374{ }^{\circ} \mathrm{C}$ in DTA may be attributed to removal of coordinated part of creatinine ligand. The third step of decomposition is sharp from $400{ }^{\circ} \mathrm{C}$ to $1000{ }^{\circ} \mathrm{C}$ with mass loss of $36.09 \%$ (calcd. $35.45 \%$ ) a sharp exothermic in DTA at $547^{\circ} \mathrm{C}$ is observed for this step. The mass of the final residue $14.47 \%$ is corresponds to iron(II) oxide as end product.

The thermogram of $\mathrm{Cr}$ (III) complex show mass loss $6.69 \%$ (calcd. $7.31 \%$ ) in the range 30 ${ }^{\circ} \mathrm{C}$ to $220{ }^{\circ} \mathrm{C}$ and an endothermic peak in this region $\Delta \mathrm{T}_{\max }=205{ }^{\circ} \mathrm{C}$, indicates loss of two uncoordinated water molecules. The second step show decomposition in $220^{\circ} \mathrm{C}$ to $350{ }^{\circ} \mathrm{C}$ range with $30.91 \%$ mass loss (calcd. $36.23 \%$ ) and a broad endothermic $\Delta \mathrm{T}_{\max }=300{ }^{\circ} \mathrm{C}$ in DTA may be attributed to removal of four uncoordinated water molecules, and three chlorine atoms. The third step decomposition at $350{ }^{\circ} \mathrm{C}$ to $1000{ }^{\circ} \mathrm{C}$, with mass loss of $44.32 \%$ (calcd. $44.20 \%$ ) corresponds to decomposition of coordinated creatinine ligand, a broad exothermic in DTA is observed for this step. The mass of the final residue corresponds to stable $\mathrm{CrO}$ with mass $13.08 \%$ (calcd. $13.79 \%$ ).

The TG curve of Co(II) complex, show three step decomposition. The first step from $30{ }^{\circ} \mathrm{C}$ to $250{ }^{\circ} \mathrm{C}$, with a mass loss $4.09 \%$ (calcd. $3.88 \%$ ), an endothermic peak $\Delta \mathrm{T}_{\max }=226^{\circ} \mathrm{C}$ in DTA may be attributed to the loss of one non-coordinated water molecule. The sudden decomposition in second step from $250{ }^{\circ} \mathrm{C}$ to $550{ }^{\circ} \mathrm{C}$ with mass loss $46.79 \%$ (calcd. $45.65 \%$ ), an endothermic peak $\Delta \mathrm{T}_{\max }=360^{\circ} \mathrm{C}$ in DTA. Third decomposition slow and starts from $550{ }^{\circ} \mathrm{C}$ to $1000{ }^{\circ} \mathrm{C}$ with mass loss $27.88 \%$, an exothermic peak in DTA at $\Delta \mathrm{T}_{\max }=635^{\circ} \mathrm{C}$ due to removal of coordinated parts of creatinine ligand. The mass of the final residue $21.24 \%$ is corresponds to $\mathrm{CoO}$ oxide polluted with few carbon atoms as product.

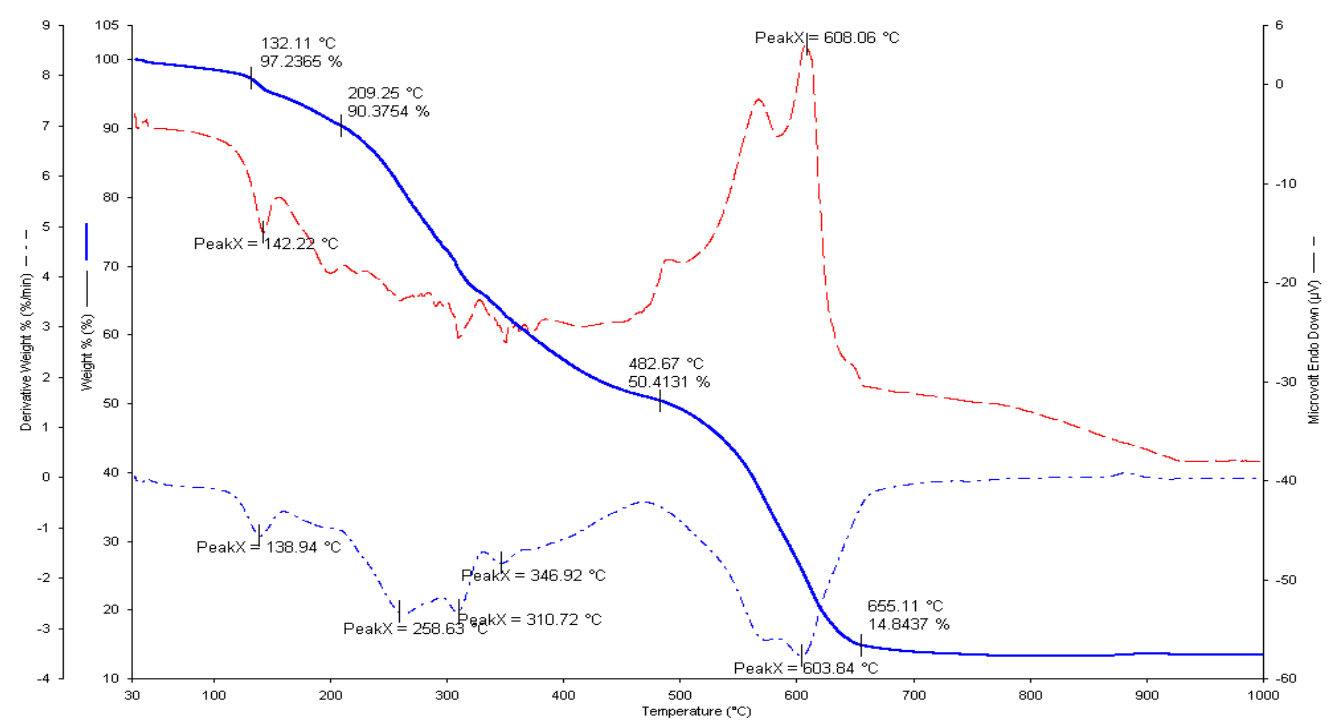

Figure 4a. TGA, DrTGA and DTA curves of manganese(II) complex. 


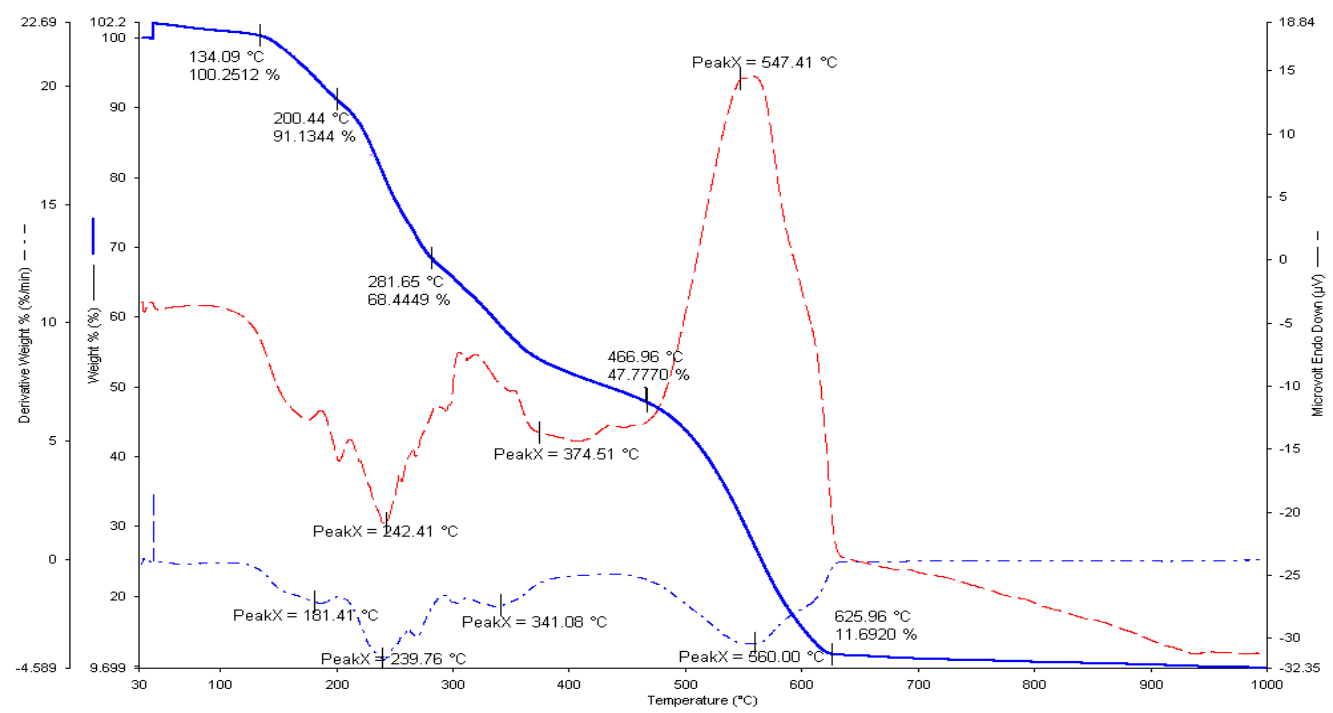

Figure 4b. TGA, DrTGA and DTA curves of iron(III) complex.

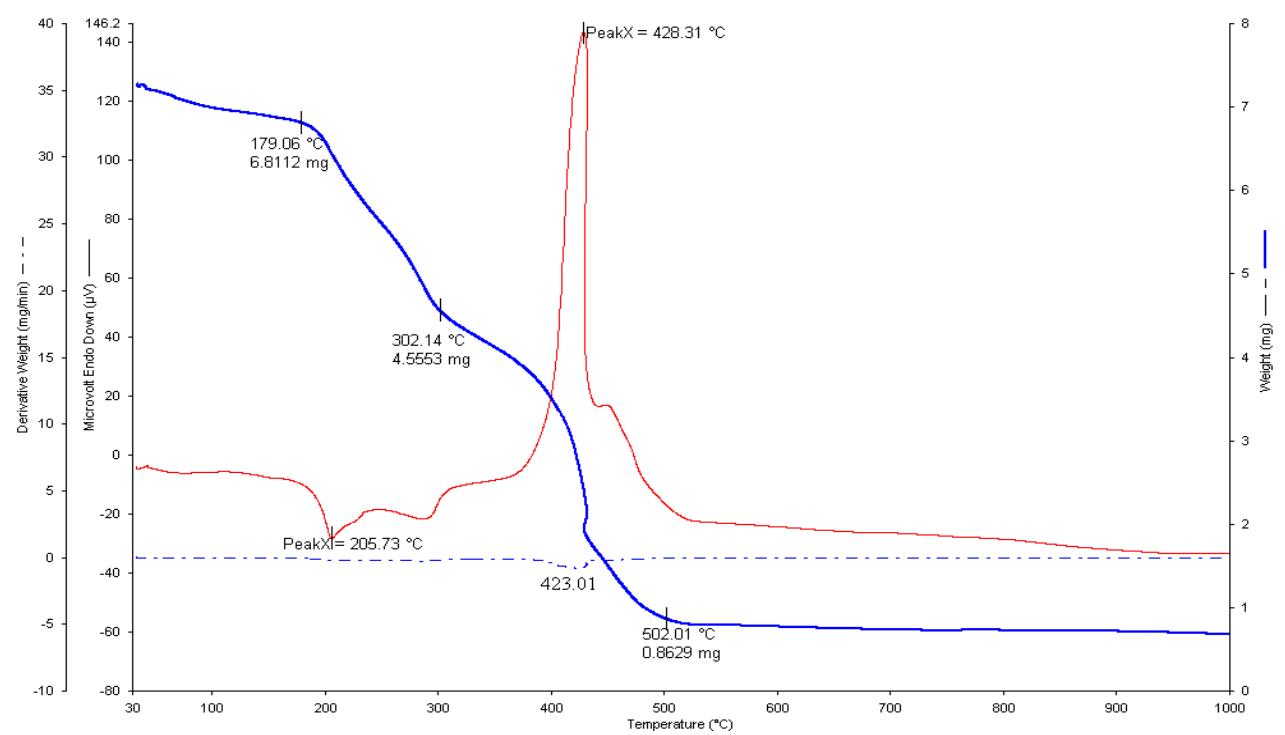

Figure 4c. TGA, DrTGA and DTA curves of chromium(III) complex. 


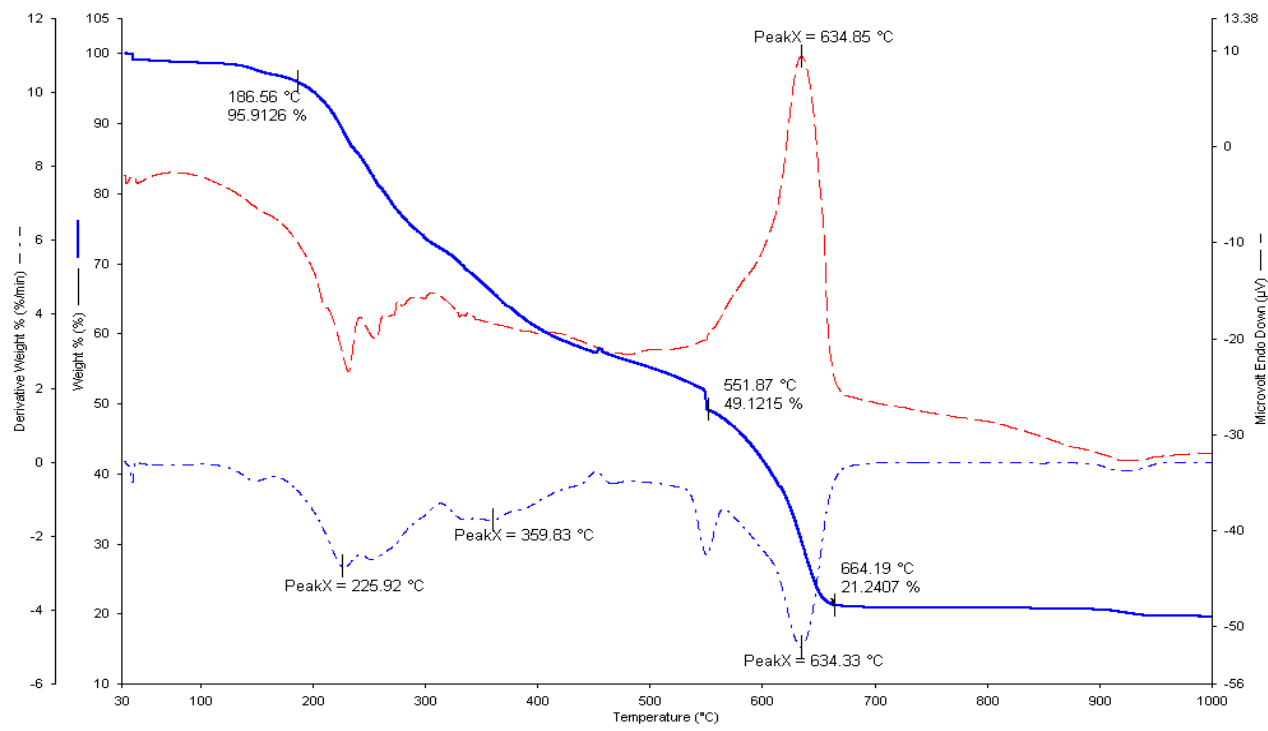

Figure 4d. TGA, DrTGA and DTA curves of cobalt(II) complex.

\section{Molecular docking studies}

The investigation of best binding site of the metal complexes into the COVID-19 protease was obtained from the molecular docking studies. The interaction between metal complexes and 6LU7 are represented in Figure 5. It was noted from the docking data (Table 3) that free energy of binding (FEB) and interacting aminoacids are very different in each chromium(III), manganese(II), iron(III) and cobalt(II) with creatinine biomolecules ligand as shown in Figure 6. In case of $\mathrm{Cr}$ (III) complex, FEB is found to be $-3.58 \mathrm{kcal} / \mathrm{mol}$ and the interacting amino acids are Asn142, Glu166, Gly170, Gly138 and Phe140. The probe molecule in case of $\mathrm{Mn}$ (II) is surrounded by the Ser46, Gln189 and the obtained binding energy is $-3.74 \mathrm{kcal} / \mathrm{mol}$. Further, the amino acid residues for Fe (III) are Glu166, Phe140, Gly170, Thr169 and FEB is found to be $-3.80 \mathrm{kcal} / \mathrm{mol}$. For, Co(II) complex, the probe molecule is interacted with amino acid residues such as Met49, Leu4, Asn142, Ser46 and Gln189. The higher binding energy was found in case of Fe(III) complex. Therefore, it has largest ability to inhibit the COVID-19 protease (6LU7) as compared to other metal complexes according to free energy of binding (FEB) and interacting aminoacids. The surface of hydrogen bond interaction is shown in Figure 7. 


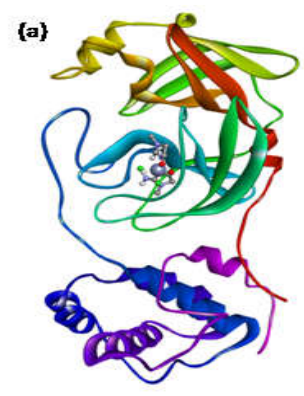

(b)
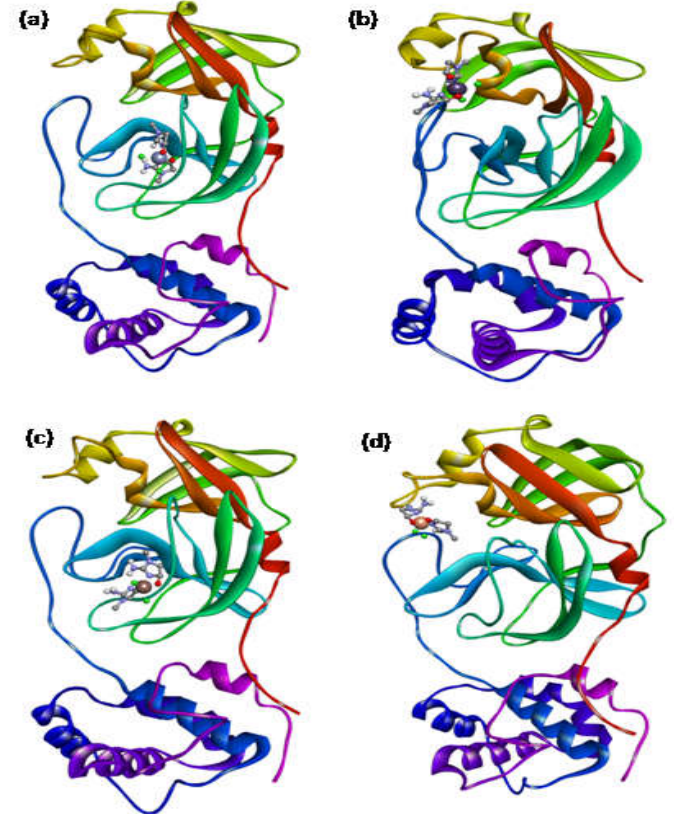

Figure 5. Helical model of Covid-19 protease docked with complexes of creatinine biomolecule ligand with metals (a) chromium(III); (b) manganese(II); (c) iron(III); and (d) cobalt, respectively.

(a)

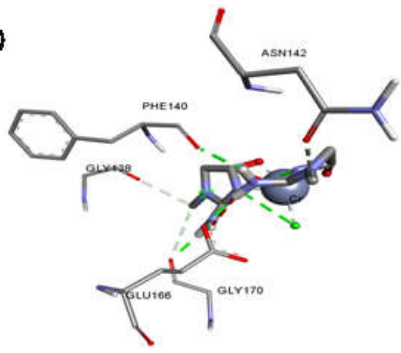

(c)

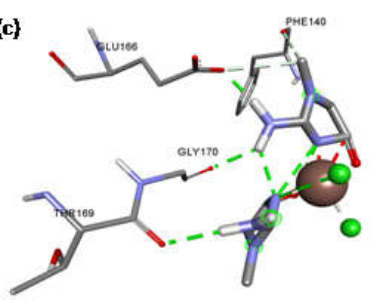

(b)

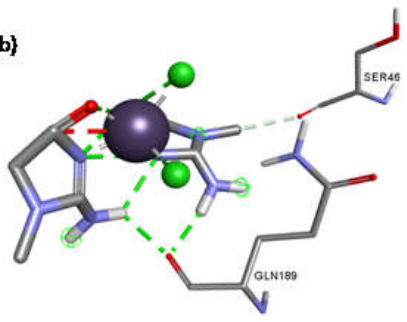

(d)

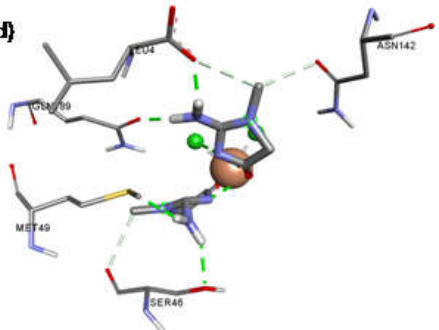

Figure 6. Docked pose showing different amino acids interacting with metal complexes of creatinine biomolecule ligand (a) chromium(III); (b) manganese(II); (c) iron (III); and (d) cobalt, respectively. 


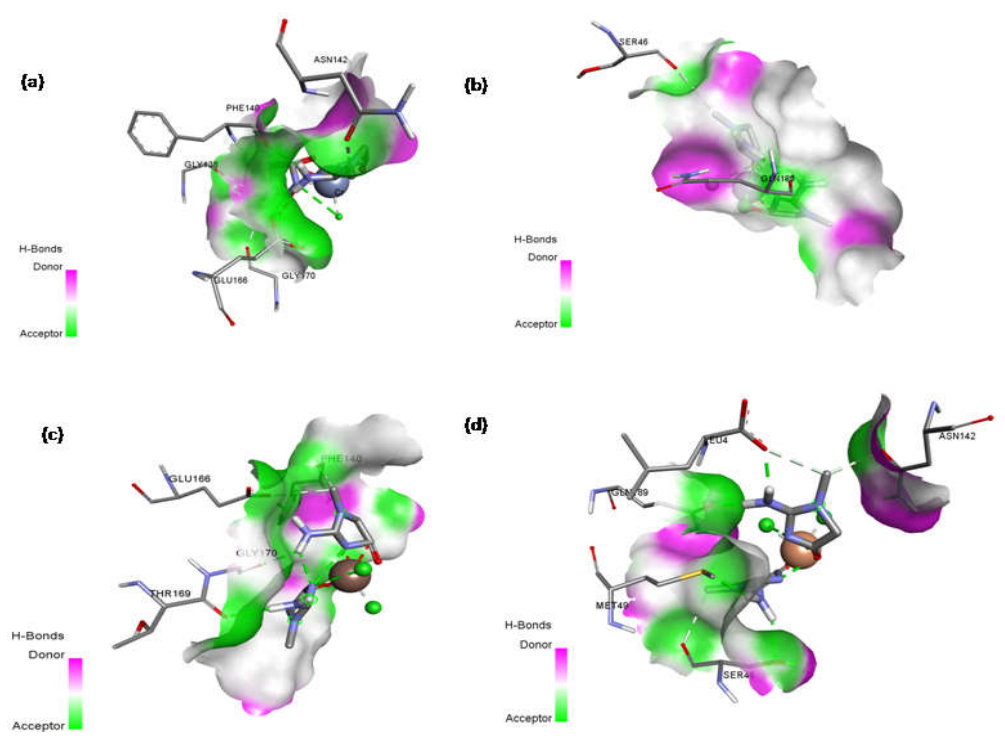

Figure 7. H-Bond interaction shown by surface of metal complexes of creatinine biomolecule ligand (a) chromium(III); (b) manganese(II); (c) iron(III); and (d) cobalt, respectively.

Table 3. All docking interaction parameters.

\begin{tabular}{|c|c|c|c|ll|}
\hline S. No. & Complexes & $\begin{array}{c}\text { Binding free } \\
\text { energy }(\mathrm{kcal} / \mathrm{mol})\end{array}$ & $\begin{array}{c}\text { Total intermolecular } \\
\text { energy }(\mathrm{kcal} / \mathrm{mol})\end{array}$ & Interacting amino acids \\
\hline 1. & Cr (III) & -3.58 & -4.13 & $\begin{array}{l}\text { Asn142, Glu166, Gly170, } \\
\text { Gly138, Phe140 }\end{array}$ \\
\hline 2. & Mn (II) & -3.74 & -4.29 & Ser46, Gln189 \\
\hline 3. & Fe (III) & -3.80 & -4.35 & $\begin{array}{l}\text { Glu166, Phe140, Gly170, } \\
\text { Thr169 }\end{array}$ \\
\hline 4. & Co (II) & -3.79 & -4.29 & $\begin{array}{l}\text { Met49, Leu4, Asn142, } \\
\text { Ser46, Gln189 }\end{array}$ \\
\hline
\end{tabular}

\section{CONCLUSIONS}

The reaction of $\mathrm{MnCl}_{2} \cdot 4 \mathrm{H}_{2} \mathrm{O}, \mathrm{FeCl}_{3} \cdot 6 \mathrm{H}_{2} \mathrm{O}, \mathrm{CrCl}_{3} \cdot 6 \mathrm{H}_{2} \mathrm{O}$, and $\mathrm{CoCl}_{2} \cdot 6 \mathrm{H}_{2} \mathrm{O}$ transition metal chloride salts with a creatinine biomolecule yielded mononuclear metal chelates $\left[\mathrm{Mn}\left(\mathrm{C}_{4} \mathrm{H}_{7} \mathrm{~N}_{3} \mathrm{O}\right)_{2}(\mathrm{Cl})_{2}\right] 4 \mathrm{H}_{2} \mathrm{O}, \quad\left[\mathrm{Fe}\left(\mathrm{C}_{4} \mathrm{H}_{7} \mathrm{~N}_{3} \mathrm{O}\right)_{2}(\mathrm{Cl})_{2}\right] \mathrm{Cl} .6 \mathrm{H}_{2} \mathrm{O}, \quad\left[\mathrm{Cr}\left(\mathrm{C}_{4} \mathrm{H}_{7} \mathrm{~N}_{3} \mathrm{O}\right)_{2}(\mathrm{Cl})_{2}\right] \mathrm{Cl}_{2} 6 \mathrm{H}_{2} \mathrm{O}$, and $\left[\mathrm{Co}\left(\mathrm{C}_{4} \mathrm{H}_{7} \mathrm{~N}_{3} \mathrm{O}\right)_{2}(\mathrm{Cl})_{2}\right] 6 \mathrm{H}_{2} \mathrm{O}$. The manganese(II) and cobalt(II) metal chelates were nonelectrolytes while the iron(III) and chromium(III) creatinine adducts were 1:2 (metal : ligand) electrolytes in dimethyl sulfoxide. The Fe(III) complex exhibited significant ability to inhibit the COVID-19 protease (6LU7) as compared to other metal complexes according to free energy of binding (FEB) and interacting aminoacids.

\section{ACKNOWLEDGEMENT}

Taif University Researches Supporting Project number (TURSP-2020/01), Taif University, Taif, Saudi Arabia. 


\section{REFERENCES}

1. Pedrozo-Peñafiel, M.J.; Lópes, T.; Gutiérrez-Beleño, L.M.; Da Costa, M.E.H.M.; Larrudé, D.G.; Aucelio, R.Q. Voltammetric determination of creatinine using a gold electrode modified with Nafion mixed with graphene quantum dots-copper. J. Electroanal. Chem. 2020, 878, 114561.

2. Zhu, W.; Wen, B.Y.; Jie, L.J.; Tian, X.D.; Yang, Z.L.; Radjenovic, P.M.; Luo, S.Y.; Tian, Z.Q.; Li, J.F. Rapid and low-cost quantitative detection of creatinine in human urine with a portable Raman spectrometer. Biosens. Bioelectron. 2020, 154, 112067.

3. Kashani, K.; Rosner, M.H.; Ostermann, M.; Creatinine: From physiology to clinical application. Eur. J. Intern. Med. 2020, 72, 9-14.

4. Udupa, M.R.; Krebs, B. Crystal and molecular structure of creatininiumtetrachlorocuprate(II). Inorg. Chim. Acta 1979, 33, 241-244.

5. Udupa, M.R.; Krebs, B. Crystal and molecular structure of bis(creatinite)silver(I) perchlorate dihydrate. Inorg. Chim. Acta 1981, 55, 153-156.

6. Muralidharan, S.; Nagaraja, K.S.; Udupa, M.R. Cobalt(II) complexes of creatinine. Trans. Met. Chem. 1984, 9, 218-220.

7. Hughes, J.L.; Liu, R.C.; Enkoji, T.; Smith, C.M.; Bastian, J.W.; Luna, P.D. Cardiovascular activity of aromatic guanidine compounds. J. Med. Chem. 1975, 18, 1077-1088.

8. Mitewa, M. Coordination properties of the bioligand creatinine and creatine in various reaction media. Coord. Chem. Rev. 1995, 140, 1-25.

9. Canty, A.J.; Fyfe, M.; Gatehouse, B.M. Organometallic compounds containing a guanidinium group. Phenylmercury(II) derivatives of creatine and creatinine. Inorg. Chem. 1978, 17, 1467-1471.

10. O'Connor, J.M.; Hübner, K.; Rheingold, A.L.; Liable-Sands, L.M. New transition metal binding modes for creatinine: Molecular structures of $\left[\left(\mathrm{C}_{4} \mathrm{R}_{4}\right) \mathrm{Ir}_{(}\left(\mathrm{C}_{4} \mathrm{H}_{7} \mathrm{~N}_{3} \mathrm{O}\right)\left(\mathrm{PPh}_{3}\right)_{2} \mathrm{Cl}\right]$ and $\left[\left(\mathrm{C}_{4} \mathrm{R}_{4}\right) \operatorname{Ir}\left(\mathrm{C}_{4} \mathrm{H}_{7} \mathrm{~N}_{3} \mathrm{O}\right)\left(\mathrm{PPh}_{3}\right)_{2}\right] \mathrm{BF}_{4},\left(\mathrm{R}=\mathrm{CO}_{2} \mathrm{CH}_{3}\right)$. Polyhedron 1997, 16, 2029-2035.

11. Parojon Costa, B.S.; Baran, E.J.; Piro, O.E. Crystal structure, IR-spectrum and electrochemical behaviour of $\mathrm{Cu}$ (creatinine) ${ }_{2} \mathrm{Cl}_{2}$. Polyhedron 1997, 16, 3379-3383.

12. Panffl, A.; Fiol, J.J.; Sabat, M.; Complexes of nickel(II) with creatinine: X-ray crystal structures and spectroscopic studies. J. Inorg. Biochem. 1995, 60, 109-122.

13. Karaderi, S.; Bilgic, D. Zinc(II) and cadmium(II) binary complexes with creatinine and their mixed-ligand complexes with L-asparagine or L-glutamic acid: Potentiometrie studies. Main Group Met. Chem. 2006, 29, 145-155.

14. Jin, Z.; Du, X.; Xu, Y.; Deng, Y.; Liu, M.; Zhao, Y.; Zhang, B.; Li, X.; Zhang, L.; Peng, C.; Duan, Y.; Yu, J.; Wang, L.; Yang, K.; Liu, F.; Jiang, R.; Yang, X.; You, T.; Liu, X.; Yang, X.; Bai, F.; Liu, H.; Liu, X.; Guddat, L.W.; Xu, W.; Xiao, G.; Qin, C.; Shi, Z.; Jiang, H.; Rao, Z.; Yang, H. Structure of Mpro from SARS-CoV-2 and discovery of its inhibitors. Nature 2020, 582, 289-293.

15. Gao, J.; Hu, Y.; Li, S.; Zhang, Y.; Chen, X.; Tautomeric equilibrium of creatinine and creatininium cation in aqueous solutions explored by Raman spectroscopy and density functional theory calculations. Chem. Phys. 2013, 410, 81-89.

16. Nakamoto, K. Infrared and Raman Spectra of Inorganic and Coordination Compounds, Wiley: New York; 1997.

17. Lever, A.B.P. Inorganic Electronic Spectroscopy, 2nd ed., Elsevier: Amsterdam; 1997. 